\title{
Use of Simple Sequence Repeat Marker to Assess the Segregating Population of Rice (Oryza sativa) in field for Grain Length Quality Parameter
}

\author{
Sanjay U. Borale and Shailesh D. Kumbhar
}

\section{ABSTRACT}

\begin{abstract}
Rice grain quality is of paramount importance in the consumer preference for rice varieties and therefore the development of rice varieties should match to the consumer preference. Assessment of segregating population of breeding material in rice for quality parameter made it possible by the use of simple sequence repeat(SSR) marker. The F2 mapping population of a cross between a long slender rice genotype VDN 1137-1-1 and a short slender rice landrace Badshabhog was studied for the inheritance of grain length and to identify the marker associated with grain type. The F2 population showed 3:1 ration for long slender to short slender grain type. This segregating population was assessed by 24 SSR markers using bulk segregant analysis. Among these 24 SSR Markers, a marker RM 147 reported polymorphism between the long slender and short slender parents and respective bulks. Genetic analysis indicated goodness of fit for single gene model indicating the association of RM147 with grain length gene in the segregating population. Therefore, SSR marker RM 147 is of immense value in the assessment of grain quality parameter in rice during the development of rice varieties.
\end{abstract}

Keywords: Rice, Grain Length quality, SSR marker, Segregating population, Marker Association.

\section{INTRODUCTION}

Rice (Oryza sativa L.) is the world's most important food crop and a primary source of food for more than half of the world's population as its main staple food. More than $90 \%$ of the world's rice is grown and consumed in Asia where $60 \%$ of the earth's people live. It is consumed by more than 3 billion Asians daily. It is planted on about 154 million hectares annually or on about $11 \%$ of the world's cultivated land [1]. It is mainly grown in large areas of Asia, Latin America and Africa that are characterized by a semitropical climate with alternating rainy and dry seasons [2]. In India, rice is the main food source for more than 60 per cent of the population and contribute a share of 45 per cent in the Indian cereal production. The consumer preference for the rice varieties varies with the people of the agro-ecological zones. The favorable grain appearance of long and slender rice is preferred by consumers in America, Africa and Southeast Asia, the short and bold rice is preferred by northern China, Japan and Korea, while the long, soft grain rice is preferred in India [3]. In Indian urban population the preference is mostly to the long and slender varieties. Therefore, breeding of rice varieties for this character is an important task to the rice breeders. Large scale screening of rice germplasm and breeding segregating population in the field, is a time consuming and tedious process. Therefore, the use of marker assisted selection is advantageous in this process. In the present studies we used 24 simple sequence repeat marker to assess their use in the detection of grain character in the segregating F2 population of rice crop.

\section{MATERIAL AND METHOD}

\section{A. Parentage of Crossing Population and Screening for Grain Character}

The $F_{2}$ mapping population was derived from a cross made between VDN 1137-1-1 and Badshabhog. The line VDN 1137-1-1 developed by Agricultural Research Station, Vadgaon (Maval) has long slender grain type whereas Badshabhog, the local type from Orissa state, India has short slender grains. The $\mathrm{F}_{2}$ population and the parents were evaluated during the rice growing season for all the quality parameters under natural conditions. The observations on grain length, grain width and length-breadth (L: B) ratio were recorded on parents and 136 randomly selected $F_{2}$ plants. Observations were recorded for grain length and grain width on ten randomly selected grains from parents and $136 \mathrm{~F}_{2}$ plants at the time of harvesting and calculated the L: B ratio. The genotypes with grain length more than $6.00 \mathrm{~mm}$ and $\mathrm{L}: \mathrm{B}$ ration $\geq 3$ was considered as long slender whereas, genotypes with grain length less than $6.00 \mathrm{~mm}$ and $\mathrm{L}: \mathrm{B}$ ration $\geq 3$ are as considered as short slender. 


\section{GENOMIC DNA EXTRACTION OF PARENTS AND CROSSING POPULATION}

Genomic DNA was extracted from the leaves of both the parents and 136 individual $\mathrm{F}_{2}$ plants by CTAB method described by Doyle and Doyle [4]. The quality and quantity of DNA were estimated spectrophotometrically using a Nano Drop (ND-1000, Wilmington, USA). Bulk segregant analysis (BSA) method as suggested by Michelmore et al. [5] was used for quick identification of SSR markers associated with grain length.

Based on phenotypic observations, two bulks viz., long slender (B1: comprising of ten long slender $\mathrm{F}_{2}$ plants) and short slender (B2: comprising of ten short slender $F_{2}$ plants) were made. These $20 \mathrm{~F}_{2}$ plants were found homozygous when screened with the SSR markers used in the study. A pooled DNA sample was prepared for each bulk by mixing in equal quantity the DNA of ten respective component $\mathrm{F}_{2} \mathrm{~S}$. The parents and the bulks were screened with 24 SSR primers (Table 1) to determine polymorphism and possible association with grain length. These markers were selected based on the information collected from the website www.gramene.org and available with us were used.

\begin{tabular}{|c|c|c|c|}
\hline $\begin{array}{l}\text { Sr. } \\
\text { No }\end{array}$ & $\begin{array}{l}\text { Primer } \\
\text { name }\end{array}$ & Forward Primer $\left(5^{\prime}-3^{\prime}\right)$ & Reverse Primer $\left(5^{\prime}-3^{\prime}\right)$ \\
\hline 1 & RM 304 & TCAAACCGGCACATATAAGAC & GATAGGGAGCTGAAGGAGATG \\
\hline 2 & RM 147 & TACGGCTTCGGCGGCTGATTCC & CCCCCGAATCCCATCGAAACCC \\
\hline 3 & RM 265 & CGAGTTCGTCCAAGTGAGC & CATCCACСАТТССАССААТС \\
\hline 4 & RM 315 & GAGGTACTTCCTCCGTTTCAC & AGTCAGCTCACTGTGCAGTG \\
\hline 5 & RM 109 & GCCGCCGGAGAGGGAGAGAGAG & CCCCGACGGGATCTCCATCGTC \\
\hline 6 & RM 154 & ACCCTCTCCGCCTCGCCTCCTC & СТССТCСTCCTGCGACCGCTCC \\
\hline 7 & RM 29 & CAGGGACCCACCTGTCATAC & AACGTTGGTCATATCGGTGG \\
\hline 8 & RM 341 & CAAGAAACCTCAATCCGAGC & СТССТССCGATCCCAATC \\
\hline 9 & RM 112 & GGGAGGAGAGGCAAGCGGAGAG & AGCCGGTGCAGTGGACGGTGAC \\
\hline 10 & RM 121 & ACCGTCGCCTTCCACTTTCCCC & TTCGGGGTTGCCGGTGATGTTG \\
\hline 11 & RM 285 & CTGTGGGCCCAATATGTCAC & GGCGGTGACATGGAGAAAG \\
\hline 12 & RM 251 & GAATGGCAATGGCGCTAG & ATGCGGTTCAAGATTCGATC \\
\hline 13 & RM 338 & CACAGGAGCAGGAGAAGAGC & GGCAAACCGATCACTCAGTC \\
\hline 14 & RM 255 & TGTTGCGTGTGGAGATGTG & CGAAACCGCTCAGTTCAAC \\
\hline 15 & RM 270 & GGCCGTTGGTTCTAAAATC & TGCGCAGTATCATCGGCGAG \\
\hline 16 & RM 42 & ATCCTACCGCTGACCATGAG & TTTGGTCTACGTGGCGTACA \\
\hline 17 & RM16 & CGCTAGGGCAGCATCTAAA & AACACAGCAGGTACGCGC \\
\hline 18 & RM60 & AGTCCCATGTTCCACTTCCG & ATGGCTACTGCCTGTACTAC \\
\hline 19 & RM21 & ACAGTATTCCGTAGGCACGG & GCTCCATGAGGGTGGTAGAG \\
\hline 20 & RM229 & CACTCACACGAACGACTGAC & CGCAGGTTCTTGTGAAATGT \\
\hline 21 & RM515 & TAGGACGACCAAAGGGTGAG & TGGCCTGCTCTCTCTCTCTC \\
\hline 22 & RM72 & CCGGCGATAAAACAATGAG & GCATCGGTCCTAACTAAGGG \\
\hline 23 & RM125 & ATCAGCAGCCATGGCAGCGACC & AGGGGATCATGTGCCGAAGGCC \\
\hline 24 & RM481 & TAGCTAGCCGATTGAATGGC & CTCCACCTCCTATGTTGTTG \\
\hline
\end{tabular}

\section{POLYMERASE CHAIN REACTION}

The PCR protocol involved a total volume of $20 \mu \mathrm{L}$ containing $20 \mathrm{ng}$ genomic DNA, $0.1 \mu \mathrm{M}$ of each primer, 2.0 $\mu \mathrm{L}$ of $10 \times$ Taq DNA polymerase buffer (100 mMTris $\mathrm{pH}$ 9.0, $500 \mathrm{mMKCl}), 200 \mu \mathrm{M}$ of each dNTPs and $1 \mathrm{U}$ of Taq DNA polymerase. The reaction profile was $5 \mathrm{~min}$ at $95{ }^{\circ} \mathrm{C}$, 40 cycles of $30 \mathrm{~s}$ at $94{ }^{\circ} \mathrm{C}, 30 \mathrm{~s}$ at $55^{\circ} \mathrm{C} / 60{ }^{\circ} \mathrm{C}$ annealing, 1 min at $72{ }^{\circ} \mathrm{C}$ and $10 \mathrm{~min}$ at $72{ }^{\circ} \mathrm{C}$ for final extension. The PCR products were electrophoresed on agarose gel $(2.5 \%)$ and visualized on Gel Documentation System (Flour ChemTM Alpha Innotech Corporation, San Leandro, USA). The SSR marker found polymorphic among the parents and the bulks was used for $\mathrm{F}_{2}$ progeny analysis.

The clearly resolved alleles of SSR were scored manually as homozygote for the allele for short slender (0), homozygote for the allele for long slender parent (1) and homozygote for the allele (2) in the data sheet. Chi-square $(\chi 2)$ test was performed to test the goodness of fit of the $F_{2}$ population for the phenotypic and marker data by comparing an observed frequency distribution with an expected one and was analysed by Simple linear regression method to estimate association among marker and character in a spread sheet.

\section{RESULTS AND DISCUSSION}

The rice grain of crossing parent VDN 1137-1-1 was found long slender while that of Badshabhog was found short slender in the field. Among the randomly selected 136 F2 progeny plants, 105 plants showed long slender grain type and 31 plants showed short slender grain type. The observed frequencies when tested for goodness of fit with chi-square $(\chi 2)$ test for single gene model showed goodness of fit $(\mathrm{P}=0.038)$ to the expected segregation ratio $(3: 1)$ (Table 2).

TABLE 2: PhenOtyPic EVALUATION OF THE F2 POPULATION

\begin{tabular}{ccccccc}
\hline $\begin{array}{c}\text { S. } \\
\text { No. }\end{array}$ & Category & $\begin{array}{c}\text { Observed } \\
\text { phenotype }\end{array}$ & $\begin{array}{c}\text { Expected } \\
\text { phenotypes }\end{array}$ & $\begin{array}{c}\chi^{2} \\
\text { value }\end{array}$ & $\begin{array}{c}P \\
\text { value }\end{array}$ & $\begin{array}{c}\text { Observed } \\
\text { ratio }\end{array}$ \\
\hline 1 & $\begin{array}{c}\text { Long } \\
\text { slender }\end{array}$ & 105 & 102 & 0.602 & 0.038 & $3: 1$ \\
2 & $\begin{array}{c}\text { Short } \\
\text { slender }\end{array}$ & 31 & 34 & & & \\
3 & Total & 136 & 136 & & & \\
\hline
\end{tabular}

Among the 24 SSR markers used, only one marker i.e., RM 147 reported polymorphism between long slender and short slender parents and corresponding bulks indicating their possible association with grain length in the mapping population. The $F_{2}$ mapping population was assessed with this primer to study its possible association with grain length. Segregation study with marker RM147 recorded an allele of $\sim 154 \mathrm{bp}$ amplified in 98 plants, whereas an alleles 
of $\sim 161$ bp and $\sim 154$ bp were amplified in 38 plants (Table 3; Fig. 1).

TABLE 3: Molecular Evaluation OF THE F2 POPUlation WiTH SSR MARKER RM 147

\begin{tabular}{cccccc}
\multicolumn{6}{c}{ MARKER RM 147 } \\
$\begin{array}{c}\text { S. } \\
\text { No. }\end{array}$ & Category & $\begin{array}{c}\text { Observed } \\
\text { phenotype }\end{array}$ & $\begin{array}{c}\text { Expected } \\
\text { phenotypes }\end{array}$ & $\begin{array}{c}\chi^{2} \\
\text { value }\end{array}$ & $\begin{array}{c}P \\
\text { Value }\end{array}$ \\
\hline 1 & $\begin{array}{c}\text { Long } \\
\text { slender }\end{array}$ & 98 & 102 & 0.627 & 0.039 \\
2 & $\begin{array}{c}\text { Short } \\
\text { slender }\end{array}$ & 38 & 34 & & \\
3 & Total & 136 & 136 & & \\
\hline
\end{tabular}

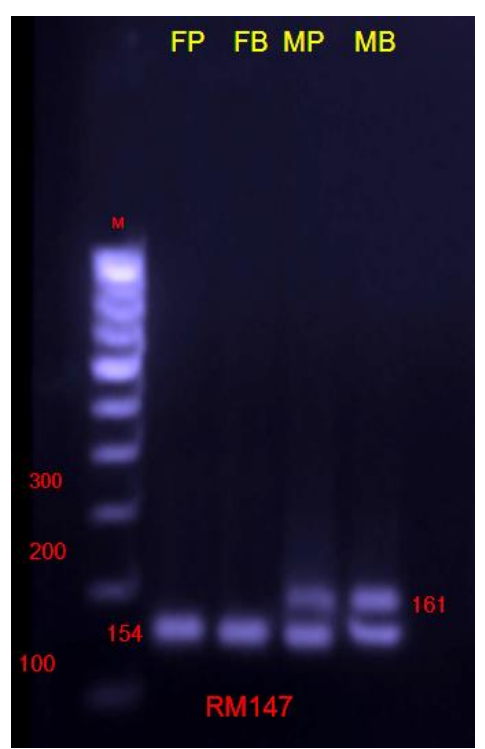

Fig. 1. Bulk segregant analysis with SSR marker RM 147.

Genetic analysis with chi-square test indicated goodness of fit to the expected ratio of 3:1 for single gene model indicating the association of RM147 with grain length gene in the present population. This confirmed that the grain length in rice in present investigation was governed by single gene. The simple regression analysis between phenotypic data of grain length and the genotypic data of SSR marker RM147 indicated that the marker was significantly linked with grain length (Table 4).

TABLE 4: ANOVA FOR REGRESSION ANALYSIS FOR SSR MARKER RM147 WITH PHENOTYPIC DATA

\begin{tabular}{ccccccc}
\hline S. & Source & $\begin{array}{c}\text { Degrees } \\
\text { of } \\
\text { freedom }\end{array}$ & $\begin{array}{c}\text { Sum of } \\
\text { squares }\end{array}$ & $\begin{array}{c}\text { Mean } \\
\text { sum of } \\
\text { squares }\end{array}$ & F & $P$ \\
\hline 1 & Regression & 1 & 8.87 & 8.87 & $67.51^{* *}$ & 3.911 \\
2 & Residual & 134 & 17.60 & 0.13 & & \\
3 & Total & 135 & 26.47 & & & \\
\hline
\end{tabular}
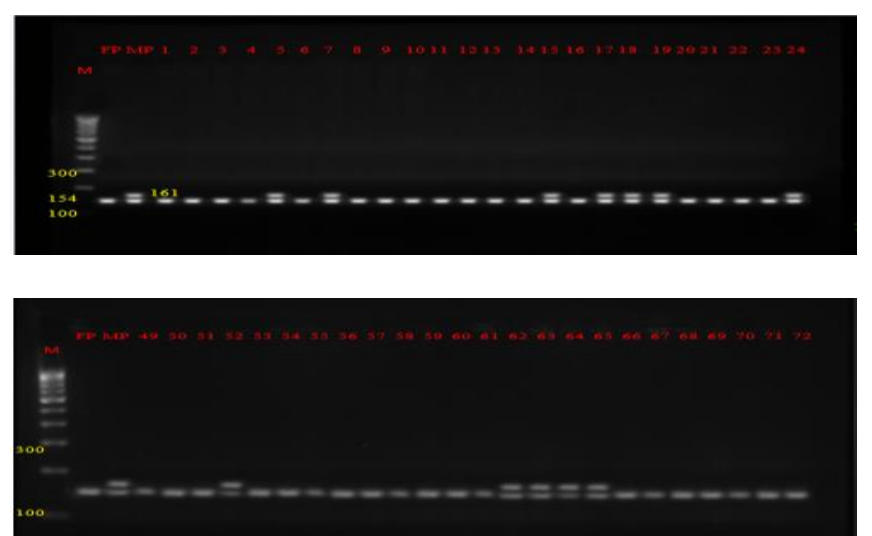

Fig. 2. Validation on individual $F_{2}$ plants with SSR marker RM 147.
New genetic tools, such as molecular markers provide a new alternative selection approach to enhance genetic improvements in crops. Molecular study in relation with the grain length is very important for the grain quality in rice. In order to identify the new sources of quality traits, there is need for identification of new quality genes in genetically diversified rice material. Independent studies have identified many QTLs associated with rice grain length using primary mapping populations [6]-[8]. During the last few years, genetics of rice grain length has been extensively studied and many genes associated with grain length were mapped on rice chromosomes 1, 3 and 10 [6], [9]-[11]. Chromosome 10 of rice has been reported to contain important genes and QTLs for grain size, especially grain length. In the present study, the SSR marker RM147 which was found associated with grain length (through BSA) segregated in 3:1 ratio confirming the single gene control. The results obtained in this study are in accordance with several earlier reports [6], [12]-[16]. However, it should be noted that the material used in the present study was totally different from the one used in by earlier workers [12]-[16]. The SSR marker RM147 has been used earlier by Pal et. al. [17], Jiang et.al [18] and Bai et al. [19], on the long arm of chromosome 10 explaining $30.7 \%$ phenotypic variation.

The genetic makeup of a particular variety dictates to a large extent the grain quality in rice. Plant breeders persistently refine and improve genetic traits of new varieties required to produce. The QTLs related to yield potential and grain length have been detected by using the genetic linkage maps. Independent studies have identified many QTLs associated with rice grain length using primary mapping populations [6], [20], [21]. The identification of QTLs for grain length and identification of their genetic control are necessary for the development of MAS strategies aimed at improving breeding efficiency. Molecular marker technology offers such a possibility and therefore are useful for mapping genes of interest, marker-assisted breeding and cloning genes by map-based cloning strategies. Molecular study in relation with the grain length is very important from the quality point of view as the consumers either prefer long slender / short slender with aroma and other quality characters.

Marker assisted selection (MAS) has been applied for integrating different quality genes into rice cultivars which lacks into them. In order to identify the new sources of quality traits, there is need for identification of new quality genes in genetically diversified rice material. In the present investigation the inheritance of grain length in $\mathrm{F}_{2}$ mapping population and the genes/QTLs associated with it was studied. The ultimate objective of present study was to create a genetic mapping resource in the form of recombinant inbred lines (RILs) for future genetic studies from the population derived in the present study.

In present investigation, wide variation was observed for the grain length in the parental genotypes as well as in the $F_{2}$ population. This indicated that the parental genotypes used in the present study for developing the population was an appropriate choice and a permanent genetic stock in the form of RILs can be developed from the present $F_{2}$ population. The phenotypic data on the grain length showed that the grain length is governed by single dominant gene. 


\section{CONCLUSION}

The present study indicated that the SSR marker RM147 is associated with grain length gene/locus in the rice and also highlight the importance of BSA in establishing marker-trait association in a rapid way. The findings of this study could be directly useful in molecular analysis of segregating generations, breeding lines and varieties of rice for the grain quality trait. This marker can detect the rice grain quality trait in the segregating populations of rice under field at an early growing plant stage and therefore can save lot of time and efforts in the identification of grain quality trait and development of consumer preferred rice varieties.

\section{REFERENCES}

[1] Gadal,N., Shrestha, J., Poudel,M.N and Pokhrel, B. 2019. A review on production status and growing environment of rice in Nepal and in the world. Archives of Agriculture and Environmental Science. 4(1): 83-87.

[2] Rao, S. A., Khan, M. A., Mc Nailly, T. and Khan, A. A., 1997. Cause and effect relationships of yield and yield components in rice (Oryza sativa L.). J. Genet. Breed, 15(1): 1-5.

[3] Calingacion, M., Laborte, A., Nelson, A., Resurreccion, A., Concepcion, J. C., Daygon, V. D., Mumm, R., Reinke, R., Dipti, S., Bassinello, P. Z., Manful, J., Sophany, S., Lara, K. C., Bao, J. S., Xie, L. H., Loaiza, K., El-hissewy, A., Gayin, J., Sharma, N., Rajeswari, S., Manonmani, S., Rani, N. S., Kota, S., Indrasari, S. D., Habibi, F., Hosseini, M., Tavasoli, F., Suzuki, K.,Umemoto, T., Boualaphanh, C., Lee, H. H., Hung, Y. P., Ramli, A., Aung, P. P., Ahmad, R., Wattoo, J. I., Bandonill, E., Romero, M., Brites, C. M., Hafeel, R., Lur, H. S., Cheaupun, K., Jongdee, S., Blanco, P., Bryant, R., Lang, N. T., Hall, R. D., Fitzgerald, M., 2014 Diversity of global rice markets and the science required for consumer-targeted rice breeding. PLoS One 9: e85106. https://doi.org/10.1371/journal.pone.0085106.

[4] Doyle, J.J., and Doyle, J.L. 1990. Isolation of plant DNA from fresh tissues. Focus. 12: 13-15.

[5] Michelmore, W. R., Paran, I and Kesseli,R.V. 1991. Identification of marker linked to diseases resistance genes by bulked segregants analysis, a rapid method to detect the markers in specific genetic region by using the segregating population. Proc. Natl. Acad. Sci. USA 88: 9828-9832.

[6] Huang, Ning., Parco, A., Mew, T., Magpantay, G., McCouch, Susan., Guiderdoni, E., Xu, J., Subudhi, P., Angeles, E. R. and Khush G. S., 1997. RFLP mapping of isozymes, RAPD and QTLs for grain shape, brown plant hopper resistance in a doubled haploid rice population. Molecular Breeding.3:105-113.

[7] Pal, Surender., Jain, S., Saini, N. Aarti and Jain, R. K., 2004. Identification of microsatellite markers for differentiating some Basmati and non- Basmati rice varieties. J. of Biotechnology.vol.3: 519-526.

[8] Li, Jiming., Jinhua, X., Silvana, G., Longying, Jiang., Wan, Y., Qiyun, D., Longping, Y., and McCouch, S. R. 2004. QTL detection for rice grain quality traits using an interspecific backcross population derived from cultivated Asian (O. sativaL.) and African (O. glaberrimaS.) rice. Genome 47: 697-704.

[9] Wang, X. Y., Wan, J. M., Jiang, L., Wang, J. K., Zhai, H. Q., Weng, J. F., Wang, H. L., Lei, C. L., Wang, J. L., Zhang, X., Cheng, Z. J. and Guo, X. P., 2006. QTL analysis for rice grain length and fine mapping of an identified QTL with stable and major effects. Theor. Appl. Genet. 112: 1258-1270.

[10] Li, Mao-mao., Xu, lei., Ren, Jun-fang., Cao, Gui-lan., Yunli-qin., He, Hao-hua., Han, Long zhi and Ko, h. 2010. Identification of quantitative trait loci for grain traits in japonica rice. Agricultural Sciences in China. 9(7): 929-936.

[11] Singh, Yogendra and Singh, U.S. 2012.Simple Sequence Repeats markers and grain quality characteristics for genetic divergence and selective identification of Aromatic rices. International J. Adv. Biotec.\& Res. 3: 711-719.

[12] Chen, X., Temnykh, S., Xu, Y., Cho, Y. G., McCouch, S. R. 1997. Development of microsatellite framework map providing genomewide coverage in rice (Oryza sativa L.). Theor. Appl. Genet. 95: 553567.
[13] Lang, N.T., Khush, G.S., Huang, N. and Bau, B.C., 2001. Fine mapping for blast resistance gene in rice (Oryza sativa L.) using bulked segregrant analysis. Omon rice $9: 1-8$.

[14] Zhou, J. H., Wang, J. L., Xu, J. C., Lei, C. L. and Ling, Z. Z., 2004 Identification and mapping of rice blast resistance gene $P i$-g(t) in the cultivar Guangchangzhan. Plant Pathol. 53 (2): 191-196.

[15] Lee, S., Wamishe, Y., Jia, Y and Liu,G. 2009. Identification of two major resistance genes against race IE-1k of Magnaporthe oryzae in the indica rice cultivar Zhe733. Mol. Breeding. 24: 127-134.

[16] Ashkani, A., Rafii M.Y., Sariah M., Siti, Nor Akmar M., Rusli I., Abdul, R A. and Latif, M. A., 2011. Analysis of simple sequence repeat markers linked with blast disease resistance genes in a segregating population of rice (Oryza sativa). Gen. Mol. Res. 10(3): 1345-1355.

[17] Pal Surender., Jain, S., Saini, N. Aarti., and Jain, R.K. 2004. Identification of microsatellite markers for differentiating some Basmati and non Basmati rice varieties. J. of Biotechnology. Vol.3: 519-526.

[18] Jiang, G.H., Xue-Y. H., Cai-Guo, X. U., Xiang-Hua L. I. and YuQing, H.E. 2005. Identification of quantitative trait loci for grain appearance and milling quality Using a doubled-haploid rice Population. J. Integrative Pl. Bio. (Formerly Acta Botanica Sinica), 47(11): 1391-1403.

[19] Bai, Xu feng., Luo, L. , Yan, W. , Kovi, Mallikarjuna R., Zhan, W. and Xing, Y. 2010. Genetic dissection of rice grain shape using a recombinant inbred line population derived from two contrasting parents and fine mapping a pleiotropic quantitative trait locus qGL7. BMC Genet.11:16 (doi: 10.1186/1471-2156-11-16).

[20] Rabiei, B., Valizadeh, M., Ghareyazie, B., Moghaddam, M. and Ali, A. J.2004. Identification of QTLs for rice grain size and shape of Iranian cultivars using SSR markers. Euphytica. 137: 325-332.

[21] Wan, X.Y., Wan, J.M., Weng, J.F., Jiang, L., Bi, J.C., Wang, C.M., Zhai, H.Q., 2005. Stability of QTLs for rice grain dimension and endosperm chalkiness characteristics across eight environments Theoretical and Applied Genetics .110: 1334-1346. 